\title{
Assessment of soil quality for vineyard fields: A case study in Menderes District of Izmir, Turkey
}

\author{
Belgin Doğan a, Coşkun Gülser b,*
}

a Menderes Rural Directorate of Agriculture, Izmir, Turkey

b Ondokuz Mayıs University, Faculty ofAgriculture, Department of Soil Science and Plant Nutrition, Samsun, Turkey

\begin{abstract}
This study was carried out to determine the suitable classification of soil quality for vineyard fields of Akçaköy, Çatalca, Efemçukuru, Görece and Yeniköy villages in Menderes district of Izmir-Turkey. In vineyard fields, soil $\mathrm{pH}$ gave a positive relation with $\mathrm{Ca}$ and significant negative relations with $\mathrm{P}, \mathrm{Fe}, \mathrm{Mn}$ and $\mathrm{Zn}$ contents. Soil organic matter (OM) content had significant positive relations with EC, $\mathrm{P}, \mathrm{Fe}, \mathrm{Mn}$ and $\mathrm{Zn}$ and significant negative relations with bulk density and $\mathrm{CaCO}_{3}$ content. Soil quality index values for the vineyard fields varied between 0.38 and 0.85 with a mean of 0.57 . Only one of the 28 soil samples taken from different vineyard fields was found in very suitable $\left(\mathrm{S}_{1}: 1.00-0.75\right)$ class, 8 in suitable $\left(\mathrm{S}_{2}: 0.75-060\right), 12$ in marginal suitable $\left(\mathrm{S}_{3}: 0.60-0.50\right)$ and 7 in nonsuitable $(\mathrm{N}:<0.50)$ class according to the soil quality index (SQI). Restricting soil factors for vine growth in the fields classified in $S_{2}$ and $S_{3}$ classes generally became low $\mathrm{pH}$, low organic matter (OM), $\mathrm{P}, \mathrm{Fe}, \mathrm{Mn}, \mathrm{Cu}, \mathrm{Mg}$ and $\mathrm{K}$ contents than that of suggested levels. In addition to restring factors in $\mathrm{S}_{2}$ and $\mathrm{S}_{3}$ classes, physical properties in soils classified in $\mathrm{N}$ class were lower than suggested levels. The SQI values showed significant positive relations with grape yield, soil $\mathrm{OM}, \mathrm{P}, \mathrm{K}, \mathrm{Fe}, \mathrm{Cu}, \mathrm{Mn}, \mathrm{Zn}$ contents and significant negative relations with soil $\mathrm{pH}$, exch. $\mathrm{Ca}$ and $\mathrm{CaCO}_{3}$ contents. The grape yields had also positive relations with soil $\mathrm{OM}, \mathrm{Fe}, \mathrm{Mn}, \mathrm{Zn}$ contents and negative correlations with soil $\mathrm{pH}$ and $\mathrm{CaCO}_{3}$ content. Soil quality in a vineyard field should be assessed to reach successful sustainable and precision agricultural practices for high crop production.

Keywords: Soil quality, grape, yield, soil properties.
\end{abstract}

(C) 2019 Federation of Eurasian Soil Science Societies. All rights reserved

\section{Introduction}

Soil quality is defined as "the capacity of a specific kind of soil to function, within natural or managed ecosystem boundaries, to sustain plant and animal productivity, maintain or enhance water and air quality, and support human health and habitation" (Karlen et al., 1997). These functions of soils in many soil quality definitions include a soil's role in plant growth, hydrology, biological transformations, and degradation of organic materials. The sustainability and productivity of field use can be affected by the quality of soil which is controlled by chemical, physical, and biological components of a soil and their interactions (Papendick and Parr, 1992). While physical soil quality indicators are generally related to aeration, water storage and movement, chemical soil quality indicators are related to nutrient availability, phytotoxicity of trace metals, and pesticide mobility in soils (Doran and Parkin, 1994). The soil properties interact each other are generally related with topography, land use and management practices (Ekberli and Kerimova, 2005; Karaca and Gülser, 2015; Karaca et al., 2018; Kars and Ekberli, 2019).

The vine can grow in most soil types where many crop fields cannot grow. However, the soils including very heavy texture, poor drainage, salty and toxic substances is not appropriate for vine production. In heavy textural and moist soil conditions, the roots of vine die due to low aeration and crop production decreases.

\footnotetext{
${ }^{*}$ Corresponding author.

Ondokuz Mayıs University, Faculty ofAgriculture, Department of Soil Science and Plant Nutrition, 55139 Samsun, Turkey

Tel.: +903623121919

e-ISSN: 2147-4249

E-mail address: cgulser@omu.edu.tr DOI: $10.18393 /$ ejss.551874
} 
Loamy soils including high organic matter, low water holding capacity and well drainage characteristics are generally suitable for good quality grape production (Gücüyen, 2007).

Adverse effects of intensive agricultural practices on microbial activity and modification of soil organic matter are evident in vineyards. Soils in vineyards are usually sensitive to degradation and organic matter loss due to their intrinsic properties such as; limited soil development, coarse texture, and low capacity to protect organic matter binding to soil minerals (Le Bissonnais et al., 2007; Martínez-Casasnovas and Ramos, 2009). Belmonte et al. (2018) reported that soil tillage in a vineyard reduces soil organic matter accumulation and aggregate stability while permanent vegetation cover about 20-30\% of the vineyard floor improves vineyard soil conservation. Monga et al. (1990) determined that the application of N, P, K (500:750:500 g per vine per year) produced significantly more number of bunches (167), fruit yield (53.21 $\mathrm{kg} / \mathrm{vine}$ ) than the other treatments. Mackenzie and Christy (2005), studied on the soil chemical composition effects on the composition and quality of wine grapes in two vineyards of South Australia. They found that grape juice properties such as Baumé and titratable acidity were clearly correlated with micro elements in the soil such as; $\mathrm{Ca}, \mathrm{Sr}, \mathrm{Ba}, \mathrm{Pb}$ and $\mathrm{Si}$. Arnó et al. (2012) reported that soil fertility, physical and chemical soil properties have a great importance on grape quality. They found that the soil carbonates had a great effect on grape quality probably due to the reduced availability of manganese in calcareous soils.

Aegean Region having 33.0\% of Turkey's vineyard area is ranked in the first place with $43.3 \%$ of grape production. Seedless dried grape production is done only in this region, again seedless raisins export in our country in the world ranking is also taken into account when the vineyard is indispensable for our country and our region. This region is followed by the Mediterranean Region with $19.5 \%$ of the vineyard area and the Middle South agricultural region with $18.2 \%$ of the vineyard area in Turkey (Çelik et al., 2000). Generally crop fields, fruits and vegetables cannot be cultivated on the ridge areas due to high slope. This type of field is available for vineyard growth and an important source of income for the people living in these areas (Aktaş, 2002). The objective of this study was to assessment of soil quality of vine yard fields located in Akçaköy, Çatalca, Efemçukuru, Görece and Yeniköy villages of Menderes district, Izmir-Turkey.

\section{Material and Methods}

In the study, surface soil samples (0-20 cm depth) of 28 vineyard fields were taken from Akçaköy (3), Çatalca (4), Görece (3), Efemçukuru (9) and Yeniköy (9) villages in Menderes districts of Izmir, Turkey. Locations of the vineyard fields are given in Table 1.

Table 1. Locations of soil samples taken from 28 vineyard orchards

\begin{tabular}{|c|c|c|c|c|c|c|c|}
\hline \multirow{2}{*}{ Location } & \multicolumn{2}{|c|}{ Coordinates } & \multirow{2}{*}{$\begin{array}{c}\text { Elevation } \\
(\mathrm{m})\end{array}$} & \multirow{2}{*}{ Location } & \multicolumn{2}{|c|}{ Coordinates } & \multirow{2}{*}{$\begin{array}{c}\text { Elevation } \\
\text { (m) }\end{array}$} \\
\hline & North 'N' & East 'E' & & & North 'N' & East 'E' & \\
\hline Akçaköy-1 & $38^{\circ} 15.045^{\prime}$ & $27^{\circ} 05.827^{\prime}$ & 154 & Görece-1 & $38^{\circ} 16.352^{\prime}$ & $27^{\circ} 07.579^{\prime}$ & 143 \\
\hline Akçaköy-2 & $38^{\circ} 15.055^{\prime}$ & $27^{\circ} 05.832^{\prime}$ & 153 & Görece-2 & $38^{\circ} 16.159^{\prime}$ & $27^{\circ} 07.087^{\prime}$ & 139 \\
\hline Akçaköy-3 & $38^{\circ} 14.730^{\prime}$ & $27^{\circ} 05.653^{\prime}$ & 153 & Görece-3 & $38^{\circ} 16.381^{\prime}$ & $27^{\circ} 07.612^{\prime}$ & 142 \\
\hline Çatalca-1 & $38^{\circ} 15.782^{\prime}$ & $27^{\circ} 04.378^{\prime}$ & 196 & Çatalca-3 & $38^{\circ} 14.006^{\prime}$ & $27^{\circ} 03.933^{\prime}$ & 174 \\
\hline Çatalca-2 & $38^{\circ} 15.879^{\prime}$ & $27^{\circ} 04.513$ & 201 & Çatalca-4 & $38^{\circ} 15.247^{\prime}$ & $27^{\circ} 04.769^{\prime}$ & 176 \\
\hline Efemçukuru-1 & $38^{\circ} 16.443^{\prime}$ & $26^{\circ} 59.251^{\prime}$ & 684 & Yeniköy-1 & $38^{\circ} 12.514^{\prime}$ & $27^{\circ} 01.877^{\prime}$ & 196 \\
\hline Efemçukuru-2 & $38^{\circ} 16.600^{\prime}$ & $26^{\circ} 57.995^{\prime}$ & 636 & Yeniköy-2 & $38^{\circ} 12.805^{\prime}$ & $27^{\circ} 02.529^{\prime}$ & 154 \\
\hline Efemçukuru-3 & $38^{\circ} 16.630^{\prime}$ & $26^{\circ} 57.958^{\prime}$ & 626 & Yeniköy-3 & $38^{\circ} 14.046^{\prime}$ & $27^{\circ} 03.794^{\prime}$ & 179 \\
\hline Efemçukuru-4 & $38^{\circ} 16.714^{\prime}$ & $26^{\circ} 57.920^{\prime}$ & 619 & Yeniköy-4 & $38^{\circ} 12.514^{\prime}$ & $27^{\circ} 01.877^{\prime}$ & 196 \\
\hline Efemçukuru-5 & $38^{\circ} 16.712^{\prime}$ & $26^{\circ} 57.962^{\prime}$ & 614 & Yeniköy-5 & $38^{\circ} 12.302^{\prime}$ & $27^{\circ} 01.803^{\prime}$ & 219 \\
\hline Efemçukuru-6 & $38^{\circ} 16.713^{\prime}$ & $26^{\circ} 57.934^{\prime}$ & 617 & Yeniköy-6 & $38^{\circ} 12.637^{\prime}$ & $27^{\circ} 02.265^{\prime}$ & 199 \\
\hline Efemçukuru-7 & $38^{\circ} 16.398^{\prime}$ & $26^{\circ} 59.240^{\prime}$ & 686 & Yeniköy-7 & $38^{\circ} 12.328^{\prime}$ & $27^{\circ} 01.758^{\prime}$ & 219 \\
\hline Efemçukuru-8 & $38^{\circ} 16.678^{\prime}$ & $26^{\circ} 58.003^{\prime}$ & 608 & Yeniköy-8 & $38^{\circ} 14.037^{\prime}$ & $27^{\circ} 03.791^{\prime}$ & 175 \\
\hline Efemçukuru-9 & $38^{\circ} 16.615^{\prime}$ & $26^{\circ} 57.980^{\prime}$ & 630 & Yeniköy-9 & $38^{\circ} 12.805^{\prime}$ & $27^{\circ} 02.529^{\prime}$ & 154 \\
\hline
\end{tabular}

The soil properties of the fields were determined as follows: particle size distribution by the hydrometer method (Day, 1965); bulk density (BD) by soil core method (Demiralay, 1993), soil reaction (pH) in 1:1 (w:v) soil water suspension by $\mathrm{pH}$ meter; electrical conductivity $\left(\mathrm{EC}_{25}{ }^{\circ} \mathrm{C}\right)$ in the same suspension by $\mathrm{EC}$ meter; and exchangeable cations ( $\mathrm{Ca}, \mathrm{Mg}, \mathrm{K}, \mathrm{Na}$ ) by ammonium acetate extraction (Kacar, 1994), available phosphorus by Olsen's method (Olsen et al., 1954), DTPA extractable heavy metals (Fe, Mn, Zn, Cu) according to Lindsay and Norvel (1978). The organic matter content was determined using the modified Walkley-Black method (Kacar, 1994). The lime content was determined by Scheibler Calcimeter (Nelson, 1982). Exchangeable Ca, $\mathrm{Mg}$ and $\mathrm{K}$ percentages (ECaP, EMgP, EKP) were calculated with dividing exc. cation by sum of exc. cations. Grape yield (ton/ha) and yield per vinestock (kg/vinestock) were obtained after the harvest season completed from each vineyard field in 2011. 
The following geometric mean equation was used to determine for soil quality index values for each vineyard field.

where;

$$
S Q I=\sqrt[n]{a_{1} \cdot a_{2} \cdot a_{3} \ldots a_{n}}
$$

SQI: soil quality index; a: score of each soil parameter between 1.0 and 0.2 given in Table $2, \mathrm{n}$ is number of soil parameter.

SQI values for vineyard fields were classified as;

$\mathrm{S}_{1}$ : between $1.00-0.75$ as very suitable

$\mathrm{S}_{2}$ : between $0.75-0.60$ as suitable

$\mathrm{S}_{3}$ : between $0.60-0.50$ as marginal suitable and

$\mathrm{N}:<0.50$ as non-suitable for vineyard growth.

The relationships among the experimental data were performed using the SPSS 17 software package programme.

\section{Results and Discussion}

\section{Soil properties of vineyard fields}

Descriptive statistics of some physical and chemical soil properties are given in Table 2. Clay content of vineyard fields varied between 9.99 and $37.48 \%$ with a mean of $19.96 \%$. Soil texture of the vineyard fields was classified as sandy loam (SL) in 15, sandy clay loam in 10 and clay loam (CL) in 3 fields. Kurtural (2011) reported that soils having less than $5 \%$ of stone by volume and clay loam to light clay texture have high potential for vineyard growth while sandy to sandy loam textural soils have low potential. In this study, 13 fields were found as suitable for vineyard growth according to their textural classes, but 15 fields were not suitable. The bulk density (Db) of the soils varied between $1.07 \mathrm{~g} / \mathrm{cm}^{3}$ and $1.75 \mathrm{~g} / \mathrm{cm}^{3}$. Leake (1999) reported that the ideal $\mathrm{Db}$ values in the vineyard soils should be less than $1.4 \mathrm{~g} / \mathrm{cm}^{3}$. While the Db values of 15 vineyard fields were below this critical value, the values of 13 fields were found to be higher than this value. The soil $\mathrm{pH}$ values ranged from 4.85 to 8.16 were classified as neutral in 12 , slightly alkaline in 5 , slightly acid in 3, moderately alkaline in 3, very strongly acid in 3 and moderately acid in 2 vineyard fields. Çelik (1998) reported that the $\mathrm{pH}$ values of the vineyard soils varied between 5.5 and 8.5. The most suitable soil $\mathrm{pH}$ in terms of vine cultivation is neutral (Leake, 1999), 12 soil samples were found to be ideal in this study. The electrical conductivity of the soils in the vine fields varied between $0.11 \mathrm{dS} / \mathrm{m}$ and $0.70 \mathrm{dS} / \mathrm{m}$. Lanyon et al. (2004) reported that the EC values of vine growing soils should be less than $2 \mathrm{dS} / \mathrm{m}$. According to the classification of Soil Quality Lab. Staff (1999), all of the soils were found in non-salty class. The lime contents of the soils ranged between 0.38 and $15.19 \%$ and were generally classified as low.

The organic matter contents of the vineyard fields ranged from 0.48 to $2.57 \%$ (Table 2). Kurutural (2011) reported that organic matter content of vine growing soils should be between 2 and 3\%. While the organic matter contents of 24 vineyard fields were found as low, OM contents of the 4 fields were found as suitable for vine growth. The available phosphorus contents of soils were between 1.92 and $29.55 \mathrm{mg} / \mathrm{kg}$. Lanyon et al. (2004) classified the available phosphorus content of the vineyard fields as deficient less than $25 \mathrm{mg} / \mathrm{kg}$, marginal between 25 and $35 \mathrm{mg} / \mathrm{kg}$, sufficient between 35 and $80 \mathrm{mg} / \mathrm{kg}$, and high higher than $80 \mathrm{mg} / \mathrm{kg}$. In this study, the available P content of 24 soil samples was found less than $25 \mathrm{mg} / \mathrm{kg}$ and classified as deficient.

The Ca contents and exch. Ca percentage (ECaP) values of the soil samples were between 1.85 and 31.39 $\mathrm{cmol} / \mathrm{kg}$, and between 44.33 and $91.78 \%$, respectively (Table 2). The researchers reported that the ECaP of vine grown soils should be between 60-80\% (Leake 1999; Lanyon et al., 2004). ECaP values of 6 soil samples were found less than $60 \%$ and the others were higher than this critical value. The $\mathrm{Mg}$ contents and exch. Mg percentage (EMgP) of the soils were between 1.01 and $5.97 \mathrm{cmol} / \mathrm{kg}$, and 5.99 and $42.32 \%$, respectively. Lanyon et al. (2004) reported that EMgP of the vineyard soils should be between 15-30\%. In this study, the EMgP values of 8 soil samples were found to be less than 15\%, 13 of them were between 15 $30 \%$ and 7 of them were higher than $30 \%$. The K contents and exch. $\mathrm{K}$ percentage of the soil samples were between 0.11 and $0.67 \mathrm{cmol} / \mathrm{kg}$. Researchers reported that the EKP of vineyard soils should be between 510\% (Leake, 1999; Lanyon et al., 2004). The EKP values of 4 soil samples were more than $5 \%$ and the others were lower than this value. 
Table 2. Descriptive statistics for some soil properties, soil quality index values and yields of vineyard fields ( $\mathrm{n}=28$ ).

\begin{tabular}{|c|c|c|c|c|c|c|}
\hline & Minimum & Maximum & Mean & Std. Dev. & Skewness & Kurtosis \\
\hline Clay, \% & 9.99 & 37.48 & 19.96 & 7.34 & 0.86 & 0.34 \\
\hline Silt, \% & 12.33 & 29.98 & 20.86 & 4.77 & -0.03 & -1.02 \\
\hline Sand, \% & 38.31 & 74.54 & 59.17 & 9.08 & -0.59 & 0.51 \\
\hline Bulk density, $\mathrm{g} / \mathrm{cm}^{3}$ & 1.07 & 1.75 & 1.43 & 0.18 & -0.03 & -0.64 \\
\hline $\mathrm{pH}(1: 1)$ & 4.85 & 8.16 & 6.84 & 0.93 & -0.75 & 0.01 \\
\hline $\mathrm{EC}, \mathrm{dS} / \mathrm{m}$ & 0.11 & 0.70 & 0.32 & 0.16 & 0.90 & 0.17 \\
\hline Organic Matter, \% & 0.48 & 2.57 & 1.28 & 0.58 & 0.74 & -0.20 \\
\hline Av. P, mg/kg & 1.92 & 29.55 & 11.57 & 8.88 & 0.70 & -0.81 \\
\hline $\mathrm{K}, \mathrm{cmol} / \mathrm{kg}$ & 0.11 & 0.67 & 0.28 & 0.12 & 1.35 & 2.91 \\
\hline $\mathrm{Ca}, \mathrm{cmol} / \mathrm{kg}$ & 1.85 & 31.39 & 10.57 & 7.12 & 0.99 & 0.98 \\
\hline $\mathrm{Mg}, \mathrm{cmol} / \mathrm{kg}$ & 1.01 & 5.97 & 2.51 & 1.20 & 1.22 & 1.56 \\
\hline $\mathrm{Na}, \mathrm{cmol} / \mathrm{kg}$ & 0.24 & 0.44 & 0.28 & 0.05 & 1.98 & 4.13 \\
\hline Exc. K (EKP), \% & 0.64 & 7.83 & 2.81 & 1.91 & 0.87 & 0.12 \\
\hline Exc. Ca (ECaP), \% & 44.33 & 91.78 & 72.54 & 13.17 & -0.57 & -0.57 \\
\hline Exc. $\mathrm{Mg}(\mathrm{EMgP}), \%$ & 5.99 & 42.32 & 21.94 & 10.36 & 0.53 & -0.50 \\
\hline Exc. Na (ESP), \% & 0.92 & 8.46 & 2.71 & 1.64 & 1.85 & 4.50 \\
\hline $\mathrm{CaCO}_{3}, \%$ & 0.38 & 15.19 & 2.81 & 4.09 & 1.79 & 2.21 \\
\hline $\mathrm{Fe}, \mathrm{mg} / \mathrm{kg}$ & 3.30 & 55.70 & 14.28 & 13.60 & 1.86 & 2.97 \\
\hline $\mathrm{Cu}, \mathrm{mg} / \mathrm{kg}$ & 0.58 & 2.46 & 1.38 & 0.49 & 0.48 & -0.56 \\
\hline $\mathrm{Mn}, \mathrm{mg} / \mathrm{kg}$ & 7.70 & 270.36 & 49.50 & 62.45 & 2.59 & 6.39 \\
\hline $\mathrm{Zn}, \mathrm{mg} / \mathrm{kg}$ & 0.71 & 6.97 & 1.91 & 1.58 & 2.46 & 5.75 \\
\hline Soil quality index (SQI) & 0.38 & 0.85 & 0.57 & 0.10 & 0.33 & 0.68 \\
\hline Grape yield, ton/ha & 2.50 & 25.00 & 9.69 & 6.17 & 1.03 & 0.19 \\
\hline Yield per vinestock, kg & 1.00 & 11.90 & 4.35 & 2.74 & 1.17 & 0.87 \\
\hline
\end{tabular}

The mean values of available $\mathrm{Fe}, \mathrm{Cu}, \mathrm{Mn}$, and $\mathrm{Zn}$ contents of the vineyard soils were $14.28,1.38,49.50$ and $1.91 \mathrm{mg} / \mathrm{kg}$, respectively (Table 2). While Lanyon et al. (2004) reported that available Fe contents of vineyard soils should be more than $4.5 \mathrm{mg} / \mathrm{kg}$, Holzapfel et al. (2009) reported that Fe content in vineyard soils varies between 4 and $200 \mathrm{mg} / \mathrm{kg}$. In this study, only Fe content of 2 soil samples was less $4 \mathrm{mg} / \mathrm{kg}$ and the others were higher. Lanyon et al. (2004), reported that available $\mathrm{Zn}$ content of the vineyard soils is classified as deficient less than $0.5 \mathrm{mg} / \mathrm{kg}$, marginal between $0.5-1.0 \mathrm{mg} / \mathrm{kg}$, sufficient between $1.0-2.0$ $\mathrm{mg} / \mathrm{kg}$ and high between 2.0 and $20.0 \mathrm{mg} / \mathrm{kg}$. In this study, Zn contents of the most soil samples were found as sufficient for vineyard growth. Lanyon et al. (2004) reported that Mn contents of the vine-grown soils are classified as marginal less than $2.0 \mathrm{mg} / \mathrm{kg}$ and sufficient between 2.0 and $4.0 \mathrm{mg} / \mathrm{kg}$. On the other hand, Holzapfel et al. (2009) stated that for ideal viticulture, soils should contain between 15 and $70 \mathrm{mg} / \mathrm{kg} \mathrm{Mn}$. In the study, Mn contents of 6 soil samples were less than $15 \mathrm{mg} / \mathrm{kg}$, Mn contents of 22 soil samples were higher than $15 \mathrm{mg} / \mathrm{kg}$. Lanyon et al. (2004) classified the useful $\mathrm{Cu}$ contents of grapevine-grown soils as deficient less than $0.1 \mathrm{mg} / \mathrm{kg}$, marginal between $0.1-0.2 \mathrm{mg} / \mathrm{kg}$, sufficient between $0.2-0.4 \mathrm{mg} / \mathrm{kg}$, and high more than $0.4 \mathrm{mg} / \mathrm{kg}$.

\section{Soil quality classification in vineyard fields}

The selected soil physical and chemical quality parameters were classified between 1.00 (ideal) and 0.20 (poor) according to the soil requirements of vineyard given in the literatures (Leake, 1999; Lanyon et al. 2004; Holzapfel, 2009; Kurtural, 2011) and given in Table 3.

Estimated soil quality index values for the vineyard fields varied between 0.38 and 0.85 with a mean of 0.57 (Table 2). The fields chosen in Akçaköy and Efemçukuru villages were generally found to be suitable vineyard cultivation and did not have a non-suitable class in soil quality assessment (Figure 1a). The fields chosen in Çatalca and Yeniköy villages were generally found to be non-suitable for vineyard cultivation and classified in $\mathrm{N}$ class. According to the frequency distribution of soil quality classes given in Figure $1 \mathrm{~b}$, only one (3.5\%) of the 28 vineyard fields was determined in very suitable (S1) class, and the other fields were classified as; 9 fields (28.6\%) in suitable (S2), 11 fields (42.9\%) in marginal suitable (S3) and 7 fields (25\%) in non-suitable $(\mathrm{N})$ class. 
Table 3. Suitable classes of some soil properties for vineyard growth.

\begin{tabular}{lcccc}
\hline Suitable classes & Ideal & Good & Moderate & Poor \\
\hline Score & 1.0 & 0.8 & 0.5 & 0.2 \\
\hline Soil texture* & $\mathrm{L}, \mathrm{SiCL}, \mathrm{CL}$ & $\mathrm{SiL}, \mathrm{SCL}$ & $\mathrm{SL}, \mathrm{SiC}, \mathrm{SC}$ & $\mathrm{C}, \mathrm{Si}, \mathrm{S}, \mathrm{LS}$ \\
Bulk density, g/cm & $<1.2$ & $1.2-1.4$ & $1.4-1.6$ & $>1.6$ \\
$\mathrm{pH}(1: 1)$ & $6.7-7.3$ & $6.1-6.6 \& 7.4-7.7$ & $5.5-6.6 \& 7.7-8.0$ & $<5.5 \&>8.0$ \\
$\mathrm{EC}, \mathrm{dS} / \mathrm{m}$ & $<1.5$ & $1.5-2.5$ & $2.5-4.0$ & $>4.0$ \\
Organic matter, \% & 3.5 & $2.5-3.5$ & $2.5-1.5$ & $<1.5$ \\
Phosphorus, mg/kg & $80-50$ & $50-30$ & $30-20$ & $<20$ \\
ECaP, \% & $>65$ & $65-55$ & $55-40$ & $<45$ \\
$\mathrm{EMgP}, \%$ & $>30$ & $30-20$ & $20-10$ & $<10$ \\
$\mathrm{EKP}, \%$ & $>8$ & $8-5$ & $5-3$ & $<3$ \\
$\mathrm{CaCO}, \%$ & $2-4$ & $4-8$ & $>8$ \\
$\mathrm{Zn}, \mathrm{mg} / \mathrm{kg}$ & $<2$ & $2.0-1.0$ & $1.0-0.5$ & $<0.5$ \\
$\mathrm{Mn}, \mathrm{mg} / \mathrm{kg}$ & $>2.0$ & $50-30$ & $30-15$ & $<15$ \\
$\mathrm{Cu}, \mathrm{mg} / \mathrm{kg}$ & $70-50$ & $0.4-0.2$ & $0.2-0.1$ & $<0.1$ \\
$\mathrm{Fe}, \mathrm{mg} / \mathrm{kg}$ & $>0.4$ & $25-15$ & $15-4$ & $<4$ \\
\hline
\end{tabular}

${ }^{*}$ L: loam, Si: silt, C: clay, S: sand
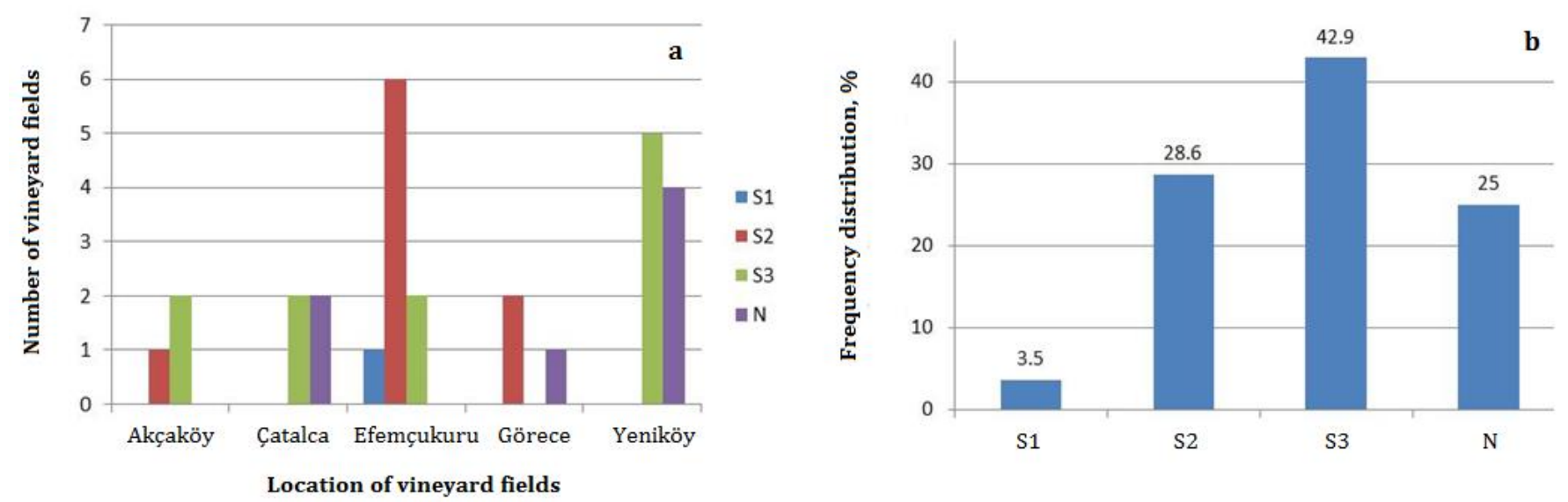

Figure 1 a) Soil quality classification of vineyard fields in different locations; b) Frequency distribution of soil quality classes in 28 vineyard fields ( $\mathrm{S}_{1}$ :very suitable $\mathrm{S}_{2}$ : suitable, $\mathrm{S}_{3}$ :marginal suitable, $\mathrm{N}$ :non-suitable).

Restricting soil factors for vine growth in the fields classified as $\mathrm{S}_{2}$ and $\mathrm{S}_{3}$ generally became lower $\mathrm{pH}, \mathrm{OM}, \mathrm{P}$, $\mathrm{Fe}, \mathrm{Mn}, \mathrm{Cu}, \mathrm{Mg}$ and $\mathrm{K}$ contents than that of the suggested levels. In addition to these restring factors in S2 and S3 classes, the physical soil properties of the vineyard fields classified as non-suitable $(\mathrm{N})$ were lower than that of the suggested levels. Arnó et al. (2012) determined that mineral concentration (basically $\mathrm{N}, \mathrm{Ca}, \mathrm{Mg}$, $\mathrm{Fe}, \mathrm{S}, \mathrm{Zn}, \mathrm{Mn}$ and $\mathrm{B}$ ) of leaves played an important role in differentiating vineyard areas of low and high production.

According to the correlation matrix among the soil properties given in Table 4, soil reaction (pH) had positive relation with exch. Ca, significant negative correlations with available $\mathrm{P}, \mathrm{Fe}, \mathrm{Mn}$ and $\mathrm{Zn}$ contents. Organic matter (OM) content had significant positive correlations with EC, $\mathrm{P}, \mathrm{Fe}, \mathrm{Mn}$ and $\mathrm{Zn}$ and significant negative correlations with $\mathrm{Db}$ and $\mathrm{CaCO}_{3}$ content. Electrical conductivity values gave significant positive correlations with clay, $\mathrm{K}, \mathrm{Ca}$ and $\mathrm{Mg}$ contents. There were also significant positive correlations among the micro nutrient contents of soils. Gülser et al. (2015) found that addition of compost and organic residue into soil increased plant available nutrient contents of the soil in a hazelnut orchard and soil organic matter content showed significant positive correlations with EC, $\mathrm{Ca}$, and sum of exchangeable cations. In another study, Candemir and Gülser (2011) reported that soil bulk density reduced with organic waste application and generally gave significant negative correlations with organic matter and other soil properties. They concluded that the soil quality parameters of clay and loamy sand soils increased by the application of different agricultural wastes. 
Table 4. Correlation matrix among the soil properties of vineyard fields.

\begin{tabular}{|c|c|c|c|c|c|c|c|c|c|c|c|c|c|c|c|c|}
\hline & $\mathrm{Si}$ & $\mathrm{S}$ & $\mathrm{Db}$ & $\mathrm{pH}$ & EC & $\mathrm{OM}$ & $\mathrm{P}$ & $\mathrm{K}$ & $\mathrm{Ca}$ & $\mathrm{Mg}$ & $\mathrm{Na}$ & $\mathrm{CaCO}_{3}$ & $\mathrm{Fe}$ & $\mathrm{Cu}$ & $\mathrm{Mn}$ & $\mathrm{Zn}$ \\
\hline $\mathrm{C}$ & 0.08 & $-0.85^{* *}$ & $-0.66^{* *}$ & 0.35 & $0.68^{* *}$ & -0.06 & -0.32 & 0.19 & $0.76^{* *}$ & $0.63^{* *}$ & $0.55^{* *}$ & $0.39^{*}$ & -0.33 & -0.36 & -0.27 & -0.13 \\
\hline $\mathrm{Si}$ & & $-0.59^{* *}$ & 0.10 & -0.02 & -0.02 & 0.09 & 0.18 & -0.05 & -0.04 & 0.06 & 0.01 & 0.35 & 0.20 & -0.04 & 0.08 & -0.05 \\
\hline$S$ & & & $0.48^{* *}$ & -0.27 & $-0.54^{* *}$ & -0.01 & 0.17 & -0.13 & $-0.60^{* *}$ & $-0.54^{* *}$ & $-0.45^{*}$ & $-0.50^{* *}$ & 0.16 & 0.31 & 0.17 & 0.13 \\
\hline $\mathrm{Db}$ & & & & -0.30 & $-0.72^{* *}$ & $-0.49^{* *}$ & 0.12 & -0.35 & $-0.64^{* *}$ & $-0.67^{* *}$ & -0.24 & 0.15 & 0.03 & 0.05 & -0.10 & -0.22 \\
\hline $\mathrm{pH}$ & & & & & 0.35 & -0.27 & $-0.63^{* *}$ & -0.22 & $0.67^{* *}$ & 0.20 & 0.18 & 0.24 & $-0.72^{* *}$ & -0.21 & $-0.53^{* *}$ & $-0.37 *$ \\
\hline EC & & & & & & $0.38^{*}$ & 0.03 & $0.42^{*}$ & $0.62^{* *}$ & $0.56^{* *}$ & 0.33 & 0.05 & -0.04 & -0.11 & 0.16 & 0.11 \\
\hline $\mathrm{OM}$ & & & & & & & $0.40^{*}$ & 0.25 & -0.09 & 0.15 & -0.22 & $-0.45^{*}$ & $0.68^{* *}$ & 0.27 & $0.71^{* *}$ & $0.57^{* *}$ \\
\hline $\mathrm{P}$ & & & & & & & & 0.15 & -0.36 & -0.17 & -0.21 & -0.05 & $0.69^{* *}$ & 0.36 & $0.65^{* *}$ & 0.33 \\
\hline K & & & & & & & & & -0.01 & $0.54^{* *}$ & 0.32 & $-0.42^{*}$ & 0.30 & 0.21 & 0.23 & 0.07 \\
\hline $\mathrm{Ca}$ & & & & & & & & & & $0.47^{*}$ & $0.47^{*}$ & 0.33 & $-0.54^{* *}$ & -0.22 & $-0.40^{*}$ & -0.21 \\
\hline $\mathrm{Mg}$ & & & & & & & & & & & $0.39^{*}$ & -0.01 & -0.06 & 0.06 & 0.02 & 0.03 \\
\hline $\mathrm{Na}$ & & & & & & & & & & & & 0.13 & -0.29 & -0.18 & -0.27 & -0.16 \\
\hline $\mathrm{CaCO}_{3}$ & & & & & & & & & & & & & -0.28 & -0.36 & -0.24 & -0.29 \\
\hline $\mathrm{Fe}$ & & & & & & & & & & & & & & $0.50^{* *}$ & $0.87^{* *}$ & $0.53^{* *}$ \\
\hline $\mathrm{Cu}$ & & & & & & & & & & & & & & & $0.51^{* *}$ & $0.39^{*}$ \\
\hline $\mathrm{Mn}$ & & & & & & & & & & & & & & & & $0.70^{* *}$ \\
\hline
\end{tabular}

The correlation matrix among the SQI, grape yield and soil properties are given in Table 5. The SQI values of the vineyard fields showed significant positive correlations with $\mathrm{OM}, \mathrm{P}, \mathrm{K}, \mathrm{Fe}, \mathrm{Cu}, \mathrm{Mn}$, $\mathrm{Zn}$ contents and significant negative correlations with soil $\mathrm{pH}$, exch. $\mathrm{Ca}$ and $\mathrm{CaCO}_{3}$ contents. Soil quality index (SQI) values of the vineyard fields had also significant positive relationships with grape yields at $1 \%$ level (Figure 2a,b).

Table 5. Relationships among the soil quality index (SQI) values, grape yield and soil properties.

\begin{tabular}{lccccccccc}
\hline & G. Yield & $\mathrm{S}$ & $\mathrm{Si}$ & $\mathrm{C}$ & $\mathrm{Db}$ & $\mathrm{pH}$ & $\mathrm{EC}$ & $\mathrm{OM}$ & $\mathrm{P}$ \\
\hline SQI & $0.747^{* *}$ & 0.286 & -0.078 & -0.304 & -0.196 & $-0.485^{* *}$ & 0.191 & $0.728^{* *}$ & $0.488^{* *}$ \\
Grape Yield & 1 & 0.248 & -0.143 & -0.214 & -0.210 & $-0.386^{*}$ & 0.238 & $0.740^{* *}$ & 0.332 \\
\hline & $\mathrm{K}$ & $\mathrm{Ca}$ & $\mathrm{Mg}$ & $\mathrm{Na}$ & $\mathrm{CaCO}_{3}$ & $\mathrm{Fe}$ & $\mathrm{Cu}$ & $\mathrm{Mn}$ & $\mathrm{Zn}$ \\
\hline SQI & $0.554^{* *}$ & $-0.447^{*}$ & 0.156 & -0.360 & $-0.657^{* *}$ & $0.728^{* *}$ & $0.424^{*}$ & $0.664^{* *}$ & $0.466^{*}$ \\
Grape Yield & 0.200 & -0.301 & 0.002 & -0.311 & $-0.420^{*}$ & $0.658^{* *}$ & 0.179 & $0.739^{* *}$ & $0.698^{* *}$ \\
\hline
\end{tabular}
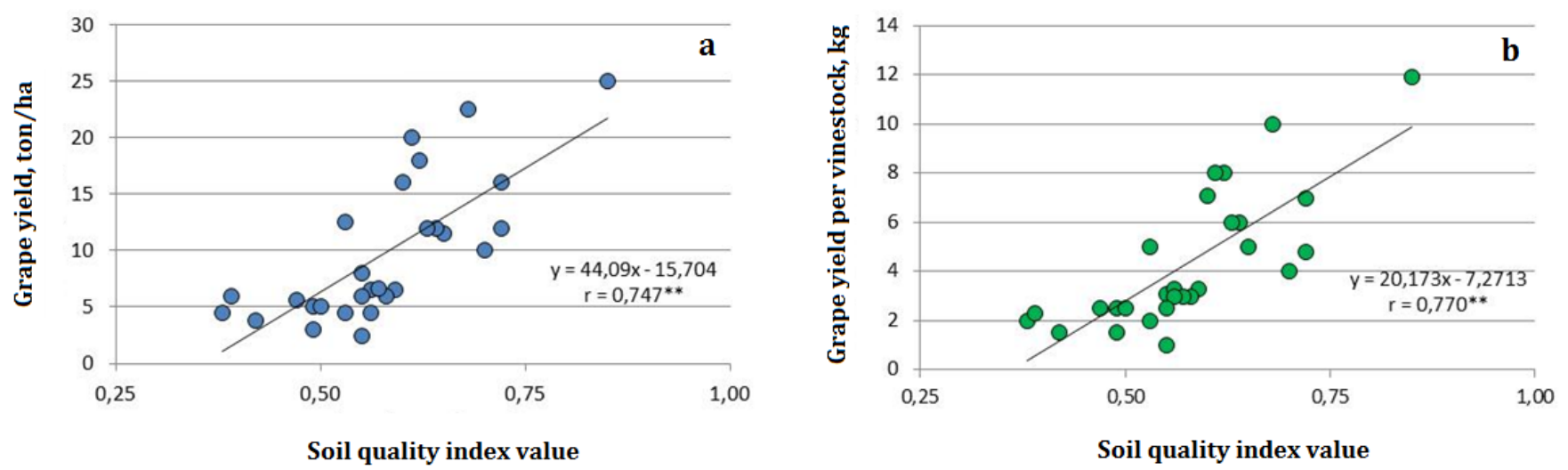

Figure 2.a) Relationship between soil quality index values and grape yields of vineyard fields,

b) Relationship between soil quality index values and grape yields per vinestock.

The grape yields of vineyard fields had positive correlations with soil OM, Fe, Mn, $\mathrm{Zn}$ contents and negative correlations with soil $\mathrm{pH}$ and $\mathrm{CaCO}_{3}$ content (Table 5). Arnó et al. (2012) reported that soil physical and chemical properties are great of importance with regard to grape yield and quality attributes, especially soil carbonate content leading to deficiency of some mineral nutrients in soil. A major threshold for soil OM is $3.5 \%$, below which a potentially serious decline in soil quality will occur (Loveland and Webb, 2003). In this study, soil OM contents generally were lower than this critical value. While the nutrient contents, grape yield and SQI values in vineyard fields increased with increasing soil OM content, the bulk density of soils 
decreased with increasing soil OM content. Aggregates are the main units of soil structure and addition of organic matter to soils improves physical quality of soil by increasing aggregate stability and decreasing bulk density (Gülser 2006; Candemir and Gülser 2011). Le Bissonnais et al. (2007) found that organic carbon content was strongly correlated with aggregate stability in 68 soil samples and it is a predominant indicator of aggregate stability of vineyard soils. It is known that there are functional relationships between plant nutrition, fertility and soil properties (Ekberli and Kerimova, 2008; Bayram and Gülser, 2018). In this study, the grape yields in vineyard fields increased with increasing SQI values due to high OM, nutrient contents and low $\mathrm{Db}$ and $\mathrm{CaCO}_{3}$ content. Demir and Gülser (2015) reported that the compost application improved soil quality with increasing the water holding capacity, $\mathrm{EC}, \mathrm{OM}$ content, exch. $\mathrm{Mg}, \mathrm{K}$ and available $\mathrm{P}$ contents and decreasing bulk density, $\mathrm{pH}, \mathrm{Na}$ and $\mathrm{Ca}$ contents, and increased tomato yield under greenhouse conditions.

\section{Conclusion}

In this study, evaluation of soil quality of 28 different vineyard fields located in Menderes district of İzmirTurkey were done according to the physical and chemical soil indicators. While the most of vineyard fields $(67.9 \%)$ classified in marginal suitable (S3) and non-suitable (N) class for vineyard growth, 32.1\% of the fields were classified in very suitable (S1) and suitable (S2) class. Restricting soil factors for vine growth were generally low $\mathrm{pH}, \mathrm{OM}, \mathrm{P}, \mathrm{Fe}, \mathrm{Mn}, \mathrm{Cu}, \mathrm{Mg}$ and $\mathrm{K}$ contents and high bulk density in the fields. Generally low $\mathrm{OM}$ content and high $\mathrm{pH}$ and $\mathrm{CaCO}_{3}$ content in the soils decreased soil quality for vine growth by decreasing the availability of nutrients and restricting soil physical properties. The grape yields of the fields had significant positive correlations with SQI values which increased by increasing the suitable soil physical and chemical characteristics in the fields for vineyard growth. It can be suggested that assessment of soil quality of the vineyard fields could play an important role for high grape productivity in precision agricultural practices.

\section{References}

Aktaş, E., 2002. Bağcılığın Türkiye Ekonomisindeki Yeri. Dünya Gıda Dergisi Sayı 7, s.1-12 [in Turkish].

Arnó, J., Rosell, J.R., Blanco, R., Ramos, M.C., Martínez-Casasnovas, J.A., 2012. Spatial variability in grape yield and quality influenced by soil and crop nutrition characteristics. Precision Agriculture 13(3): 393-410.

Bayram, S., Gülser, F., 2018. Van ilinde domatesin yaygın olarak yetiştirildiği alanların toprak özellikleri ile domates bitkisinin beslenme durumunun belirlenmesi. Yüzüncü Yll Üniversitesi Tarım Bilimleri Dergisi 28(3): 358-367 [in Turkish].

Belmonte, S.A., Celi, L., Stahel, R.J., Bonifacio, E., Novello, V., Zanini, E., Steenwerth, K.L., 2018. Effect of long-term soil management on the mutual interaction among soil organic matter, microbial activity and aggregate stability in a vineyard. Pedosphere 28(2): 288-298.

Candemir, F. Gülser, C. 2011. Effects of different agricultural wastes on some soil quality indexes in clay and loamy sand fields, Communications in Soil Science and Plant Analysis 42(1): 13-28.

Çelik, H., Marasall, B., Söylemezoğlu, G., Tangolar, S., Gündüz, M., 2000. Bağcllıkta üretim hedefleri. Türkiye Ziraat Mühendisliği V. Teknik Kongresi Bildirileri, 17-21 Ocak 2000, Ankara, Turkey. s.645-678 [in Turkish].

Çelik, S. 1998. Bağcllık (Ampeloloji), Cilt 1. Trakya Üniversitesi, Tekirdağ Ziraat Fakültesi, Bahçe Bitkileri Bölümü, Anadolo Matbaa Ambalaj San. Tic. Ltd. Ști. Baskısı, Tekirdağ. s 426 [in Turkish].

Day, P.R., 1965. Particle fractionation and particle-size analysis. In: Methods of Soil Analysis. Part I, Black, C.A. (Ed.). Agronomy No. 9. American Society of Agronomy, Madison, Wisconsin, USA. pp. p. 545- 566.

Demiralay, İ., 1993: Toprak fiziksel analiz yöntemleri. Atatürk Üniv. Ziraat Fakültesi yayınları. Erzurum, Turkey. s.111120 [in Turkish].

Demir, Z., Gülser, C., 2015. Effects of rice husk compost application on soil quality parameters in greenhouse conditions. Eurasian Journal of Soil Science 4(3): 185-190.

Doran, J.W., Parkin, T.B., 1996. Quantitative indicators of soil quality: A minimum data set. In: Methods for assessing soil quality. Doran, J. W., Jones, A.J. (Eds.). Soil Science society of America Special Publication 49: 25-37.

Ekberli, İ, Kerimova, E., 2005. Changes in some physico-chemical parameters in irrigated clay soils of Shirvan plain Azerbaijan. Journal of Faculty of Agriculture, Ondokuz Mayıs University 20(3): 54-59 [in Turkish].

Ekberli, İ., Kerimova, E., 2008. Functional relationships between fertility and some soil parameters. Asian Journal of Chemistry 20(3): 2320-2326.

Gücüyen, A., 2007. Manisa ili ve çevresinde bağcllıkta mekanizasyon durumu, sorunları ve iyi tarım uygulamalarına yönelik çözüm önerileri. Ege Üniversitesi Fen Bilimleri Enstitüsü, Yüksek Lisans Tezi, İzmir. 146s [in Turkish].

Gülser, C., 2006. Effect of forage cropping treatments on soil structure and relationships with fractal dimensions. Geoderma 131 (1-3): 33-44.

Gülser, C., Kızllkaya, R., Așkın, T., Ekberli, İ., 2015. Changes in soil quality by compost and hazelnut husk applications in a hazelnut orchard, Compost Science \& Utilization 23(3): 135-141. 
Holzapfel, B., Quirk, L., Hutton, R., Holland, J., 2009. Winegrape nutrition and use of fertilisers and other nutritional supplements to sustain production. Water \& Vine - Managing the challenge. Fact sheet No. 15. The Grape and Wine Research and Development Corporation, Adelaide, Australia.

Kacar, B., 1994. Bitki ve Toprağın Kimyasal Analizleri III. Toprak Analizleri. Ankara Üniversitesi Ziraat Fakültesi Eğitim Araștırma ve Geliștirme Vakfı Yayınları No:3. Ankara [in Turkish].

Karaca, S., Gülser, F., 2015. Some heavy metal contents related with different physiographic units and land use in Van lake basin. International Journal of Secondary Metabolite 2(2): 37-42.

Karaca, S., Gülser, F., Selçuk, R., 2018. Relationships between soil properties, topography and land use in the Van Lake Basin, Turkey. Eurasian Journal of Soil Science, 7(2): 115-120.

Karlen, D.L., Mausbach, M.J., Doran, J.W., Cline, R.G., Harris, R.F., Schuman, G.E., 1997. Soil quality: A concept, definition, and framework for evaluation. Soil Science Society America Journal 61(1): 4-10.

Kars, N., Ekberli, İ., 2019. Çarşamba ovasının buğday bitkisi altındaki topraklarının bazı fiziksel ve kimyasal özelliklerinin incelenmesi. Toprak Su Dergisi 8(1): 18-28 [in Turkish].

Kurtural, S.K. 2011. Desired Soil Properties for Vineyard Site Preparation. Universtiy of Kentucky, College of Agriculture, Cooperative Extension Service. HortFact 31-01. Available at [access date: 18.05.2018]: http://www.uky.edu/hort/sites/www.uky.edu.hort/files/documents/KF_31_01.pdf

Lanyon, D.M., Cass, A., Hansen, D. 2004. The effect of soil properties on vine performance. CSIRO Land and Water Technical Report No. 34/04 Available at [access date: 18.05.2018]: http://www.clw.csiro.au/publications/technical2004/tr34-04.pdf

Le Bissonnais, Y., Blavet, D., De Noni, G., Laurent, J.Y., Asseline, J., Chenu, C., 2007. Erodibility of Mediterranean vineyard soils: Relevant aggregate stability methods and significant soil variables. European Journal of Soil Science 58(1): 188-195.

Leake, S. 1999. Vineyard soil management. Sydney Environmental \& Soil Laboratory Pty Ltd. Australia. Available at [access date: 18.05.2018]: http://www.sesl.com.au/uploads/articles/Vineyard_Soil_Management.pdf

Lindsay, W.L., Norvell, W.A., 1978. Development of a DTPA soil test for zinc, iron, manganese, and copper. Soil Science Society of America Journal 42(3): 421-428.

Loveland, P., Webb, J.. 2003. Is there a critical level of organic matter in the agricultural soils of temperate regions: a review. Soil and Tillage Research 70(1): 1-18.

Mackenzie, D.E., Christy, A.G., 2005. The role of soil chemistry in wine grape quality and sustainable soil management in vineyards. Water Science and Technology 51(1): 27-37.

Martínez-Casasnovas, J.A., Ramos, M.C., 2009. Soil alteration due to erosion, ploughing and levelling of vineyards in north east Spain. Soil Use and Management 25(2): 183-192.

Monga, P.K., Josan, J.S., Sing, P., Kumar, B., 1990, Effect of N, P and K doses on fruit yield and quality in grapes cv. Perlette under arid irrigated region of Punjab. Indian Journal of Horticulture 47(4): 401-404.

Nelson, R.E., 1982. Carbonate and gypsum. In: Methods of Soil Analysis, Part 2, Chemical and microbiological properties, Second Edition. Number 9, Page, A.L., Keeney, D. R., Baker, D.E., Miller, R.H., Ellis, R. Jr., Rhoades, J.D. (Eds.). ASASSSA, Madison, Wisconsin, USA. pp. 181-198.

Olsen, S.R., Watenabe, V.C., Dean, L.A., 1954. Estimate of available phosphorous in soil by extraction with sodium bicarbonate. USDA Circular. No. 939, Washington, D.C., USA.

Papendick, R.I., Parr. J.F., 1992. Soil quality-The key to a sustainable agriculture. American Journal Alternative Agriculture 7(1-2): 2-3.

Soil Quality Institute Staff. 1999. Soil Quality Test Kit Guide. United States Department of Agriculture, Agricultural Research Service, Natural Resources Conservation Service, Soil Quality Institute. USA. Available at [access date: 18.05.2018]: https://efotg.sc.egov.usda.gov/references/public/WI/Soil_Quality_Test_Kit_Guide.pdf 